\title{
Impact of Coronavirus Pandemic (Covid-19) Lockdown on Small and Medium Businesses in Edo State
}

\author{
Robinson Osarumwense, OWENVBIUGIE, \\ Department of Vocational and Technical Education, Education of Faculty, University of Benin, Benin-City, Edo State, Nigeria \\ E-mail: osarumwense.owenvbiugie@uniben.edu \\ Dr. Angela Obose, ORIAZOWANLAN \\ Department of Entrepreneurship, Faculty of Management Sciences, University of Benin, \\ Benin City, Edo State, Nigeria \\ Correspondence e-mail: oboseangel@gmail.com
}

\begin{abstract}
The negative impact of COVID-19 pandemic on both lives and businesses was quite enormous. The study therefore assessed its impact on businesses in Edo State of Nigeria. It determined the effect of lockdown occasioned by the pandemic on sales volume, cash flow and profit margin of small and medium business owners amidst covid-19 era. 1119 business operators constituted the study population and a sample size of 235 respondents were randomly selected. Four research questions gave focus to the study. A 40-item structured questionnaire was used to elicit information from the respondents. The descriptive survey research design gave credence to the study. A reliability coefficient value of 0.79 was obtained with the use of Cronbach Alpha formula. The research questions were answered with mean and respondents' homogeneity determined with standard deviation. The result of the findings revealed that COVID-19 impacted negatively on sales volume, business cash flow and profit margin. It was concluded that Covid-19 being an unforeseen circumstances which was contingent truncated business growth and rendered many liquidated. It was therefore recommended that business owners should use online business transaction more often to increase sales volume, facilitate a steady cash flow and maximize profit amidst Covid-19 as well as develop other strategies to attract massive savings in order to surmount crises that could be contingent and inimical to their businesses
\end{abstract}

Keywords: Coronavirus Pandemic (Covid-19), Lockdown, Small and Medium Businesses and Edo State

DOI: $10.7176 / \mathrm{EJBM} / 13-10-07$

Publication date:May $31^{\text {st }} 2021$

Introduction

The emergency of Covid-19 is one of the unforeseen circumstances that truncated business activities globally. There has been a going concern and apprehension across the globe including Nigeria and Edo State in particular about the negative impact on businesses due to temporary closure that ruined a lot of businesses such as financial institutions, hotel and hospitality businesses, petty trading, itinerant trades and big corporations such as limited liability companies among others. The apprehension took toll on both lives and property irrespective of persons, race, colour, size, status and organisations whether big or small which in turn may have adversely affected the economy growth and development. The negative impact of Covid-19 was quite enormous and people adopted a new life style of normal by observing social distancing, special hygiene and taking special precautionary measure when relating with friends, colleagues, school mates, business associates, customers and even family members. Above all the restriction of movement across the globe including the Nigerian nation with interstate border closure affected the movement of goods and services which may have possibly affected business sales volumes, cash flow and profit margin. Ozili and Arun (2020) argued that Covid-19 is affecting the world's economy through social distancing which has invariably led to the shutdown of financial institutions, businesses, events, investments among stakeholders and the pandemic may trigger the world into recession. $\mathrm{Ng}$ (2020) noted that impact of Covid-19 affected the capital markets; tourism industries may go into extinction as a result of ban on flights and lockdowns.

The relevance of small and medium businesses to national economic development cannot be overemphasized, they remain the main stay of any economy in the world including Nigeria and they are deemed to be responsible for the overall development of economy growth and development. Small and medium businesses (SMEs) are the businesses meant for the provision of goods and services which emphasizes investment at the micro level to reduce poverty and unemployment rate and for the promotion of business links at the macro level. Hayes (2019) argued that business as an enterprise is concern with activities aimed at improving the lives of people in a given locality. The main objective of establishing a business enterprise is to satisfy customers and maximize profit to ensure continuous growth rate and expansion as well as attracting foreign investors. Unfortunately, the negative effect of the dreaded Coronavirus pandemic (COVID-19) which originated from Wuhai in China in the late 2019 and spread almost across the globe in 2020 including Nigeria took toll on both lives and businesses and the role of Chinese in the economic development of African nations is unquantifiable. The ravaging Coronavirus pandemic (COVID-19) claimed many lives globally including Nigeria. The Nigerian Centre for Disease Control (2021) reported that Nigeria recorded 159,252 confirmed cases, 139,058 discharged cases, 1,988 deaths as at 10 $0^{\text {th }}$ March, 2021 and in particular Edo State recorded 4,734 confirmed cases, 4,318 discharged cases and 184 deaths. So many other diseases outbreak happened in time past which equally affected lives and businesses 
such as Marburg virus of 1967, the Spanish flu of 1918 that claimed over 50 million lives, Smallpox of 1980 virus which claimed over 300 million lives, HIV of 1980 that claimed about 32 million lives, Rotavirus of 2008 that claimed about 453,000 children's lives, Swine-flu pandemic of 2009 that claimed about 203,000 lives across the globe, among others.

In order to mitigate the negative impact of Covid-19, government provided palliative measure for essential goods (foods and drugs) and increased its budgetary allocation from N8.83 trillion in 2019 to N10.59 trillion in 2020. The informal sector contributes a large proportion of its revenue to government coffer which were truncated by the sudden emergence of Covid-19 pandemic; investments by firms were greatly affected, decline in stock prices, increase in government spending and fall in global demand for goods and services occasioned by the restrictions on movement of people and border closures. This caused multiple negative effects on most Africa businesses especially Small and Medium Business sectors since majority of them depend solely on goods manufactured in China which are shipped to Africa. The pandemic resulted in decrease in the demand of goods and services by African nations which in turn directly affected local economies. Many business people cancelled overseas trips, thereby putting on hold goods manufactured in China as a result of border closures. Chilufa (2020) maintained that the COVID-19 affected supply chain distributions due to port closures in China and argued that no other country in Africa consumes more Chinese products than Nigeria.

COVID-19 affected businesses adversely and put so many in a precarious situation by truncating and reducing cash flow, sales volumes and profitability as well as making business owners panic about their business future in terms of sustainability, survival and growth, therefore resort to adjustments in their financial commitments to employees and business expansion by downsizing or pay half salaries. Imanche, Tasinda, Tian and Dalibi (2020) stated that due to Covid-19 pandemic so many countries experienced unprecedented economic slowdowns and shutdowns and in particular SMEs in Nigeria struggled to survive due to decline in production volumes and harsh market conditions. ACCA Canada (2020) reported that Covid-19 negatively affected employees' productivity by $52 \%$, launch of new products or services by $27 \%$ and cash flow stood at $23 \%$. The pandemic threw business into a precarious situation and the threats to lives made various governments across the world including Nigeria put measures in place to curb the spread in terms of when businesses should open for sales and the type of business that should open to customers which affected sales volumes and profit margins. Profit maximization is an important ingredient that encourages business growth vis-a-vis expansions within and outside its locations as well as encouraging foreign investors. York (2019) stated that business owners should change mode of operation and reduce cost to maximize profit by maintaining maximum cash flow, raise market bar, staying visibly connected, streamlining management costs, and making everybody sales representatives.

It is pertinent to note that many countries had total lock down of all their economic activities; but Nigeria had partial lockdown and in particular all offices and businesses in Edo State, whether government or privately owned or whether big or small business were forced to temporarily shut down. These businesses include big corporations, firms, Artisans, spare parts dealers, wholesales goods, service centres, hotels and hospitality businesses, pubic and civil services among others. It was only small businesses in the informal sector dealing on essential commodities such as food stuffs and drugs (pharmaceutical stores) which were of basic necessities to lives for survival that were allowed to open to customers with strict regulatory measures. The extent to which the lo ckdown which was occasioned by Covid-19 affected business sales volumes, cash flow and profit margin in Edo State seems uncertain. The study therefore investigated the extent and suggested intervention strategies to revamp the economy.

\section{Objectives}

The main objective of the study was to assess the impact of COVID-19 on small and medium businesses in Edo State. Specifically the study established the extent COVID-19 affected the following:

1. Sales volume of small and medium businesses.

2. Cash flow of small and medium business

3. Profit margin of small and medium business

4. The possible strategies to revamp small and medium businesses amidst COVID-19 era.

\section{Research Questions}

1. To what extent Covid-19 pandemic lockdown affected the sales volume of small and medium businesses in Edo State?

2. To what extent Covid-19 pandemic lockdown affected the cash flow of small and medium businesses in Edo State?

3. To what extent Covid-19 pandemic lockdown affected the profit margin of small and medium businesses in Edo State?

4. What are the possible strategies for effective small and medium business management amidst COVID-19 era?

\section{Literature Review}

Business is a commercial activity that involves buyers and sellers and it could be small, medium or large scale such as manufacturing, services, hybrid or merchandising. Small and medium businesses emphasize investment at the micro level, reduction of poverty and employment generation as well as the promotion of business links at the macro level. Adequate information and Knowledge, risk-propensity, social contact and innovations are key determinants for successful SMEs operations. The major forms of business include sole proprietorship, partnership, corporation and limited liability companies. Oriazowanlan, Olowo-Onyanemi and Umunna (2008) stated that there is no universally acceptable definition of SMEs and that what is regarded as SMEs is based on assessment in terms of sales volume, assets value and capital investment as well as number of employees. Duke II (2010) posited that the definition of SMEs is time-sensitive but could be based on 
indices such as assets base, annual turnover rate, capital employed, number of employees and market shares. Small and Medium Enterprises Equity Investment Scheme (SMEEIS) defined SMEs as any enterprise with a maximum assets base of \#500 Million (excluding land and working capital). Wikipedia defines business as the activity entered into for profit making which could be sole proprietorship, partnership, cooperative, liability company, franchises, company limited by liability, shares and guarantee among others. Kale (2019) posited that small businesses are the businesses in Nigeria whose contribution is critical to economic growth. It is pertinent to note that cash flow determines the solvency of a business, prescribing the availability of cash that is generated or consumed in the business and it represents revenue growth, operating margin as well as capital efficiency of a business while profitability determine the future of any business.

The negative impact of Covid-19 on the global economic and businesses in particular has been a strong distractor to investors in all spheres and strata of the economic including businesses. In particular small and medium business operations in Nigeria suffered a great set back due to cessation of movement and interstate border restrictions to curtail its spread to curtail the spread of Covid-19. Seen (2020) stated that during this time of COVID-19 crisis, businesses incur operating losses and maintained that during lockdown business meetings were held virtually and most times making it practically impossible to sign some agreed documents online, while some documents may not be visible for signature. Kim (2020) reported that the Consumer Electronics Division recorded lower earnings as a result of COVID-19 compared to a year before as well as decline in sales from TV business. In the same vein, Kilpatrick, Dess, and Barter (2020) maintained that tourism, hospitality, entertainment and air transportation suffered the negative impact of Covid-19 but businesses in consumer goods and retail faced higher financial risk especially by those having their supplies from China. Commenting on profit margin during Covid-19 pandemic, Singh (2020) reported that Puma's sales declined in the first quarter of 2020 due to impact of Coronavirus that is ravaging the global market.

The impact of Covid-19 is affecting sales volume of many businesses and White (2020) reported that Coca-Cola company global sales volumes fell by $25 \%$ in the first quarter of 2020 and stated that the company had a short fall in its sales to $\$ 8.6$ billion, representing a fall of $1 \%$ compared to the same period a year before. The Covid-19 pandemic impacted positively and negatively on Nigerian economy and other nations in other parts of the world. In Nigeria, the sales of food stuffs and drugs and its auxiliary products which are basic necessities to lives increased tremendously while non-essential goods and services received low patronage. Coonrod (2020) stressed that distiller of Missouri Ridge Distillery maximized an increase of profit in the production of hand sanitizer during covid-19 pandemic. Influencer Marketing Hub (2020) stated that YouTube videos watchers in Italy increased 20 times growth considerably compared to same period in 2019. Aman (2020) stated that the Automobile sector has been badly affected by Covid-19 resulting from the sales of vehicle dropping to 683,000 units. Aman further stated that the sales of vehicles dropped to 197,000 units of vehicles compared to 328,000 units in 2019. Shaulova (2020) revealed that during the coronavirus in African nations and Nigeria in particular the sales of over-the-counter in healthcare items increased significantly. Sales volume of pharmaceutical products grew by 30 percent compared to the same period of the previous year. Meyer (2020) stated that sales volume of apparel dropped to as low as $20 \%$. The economic crunch occasioned by Covid-19 pandemic affected cash flow in the Nigeria economy.

Cash flow could be regarded as the life blood of any business including small and medium businesses, be it privately owned or a limited liability company. Foss (2020) stated that as a result of the coronavirus pandemic, business owners are experiencing tight cash flow to run various arms of their business. Foss, Shah (2020) also stated that the major problem confronting business in this Covid-19 pandemic is the issue of cash flow which has been a hindrance to many organizations. Shah, further stated that many businesses are restructuring their operations to enhance their cash flows. Tregurtha (2020) identified the following to overcome cash flow difficulty and business uncertainties; organizations should provide business services virtually as result of social distancing as well as lockdown restrictions to control the virus spread which is capable of ruining small business cash flow. It is pertinent to note that the business needs to offer pick-up delivery service; e-commerce site or online delivery platform could be used to abate the challenges of restrictions on movements posed by Covid-19 pandemic.

The challenges posed by Covid-19 to business are enormous and it's a big blow to small and medium business across the globe including Nigeria and Edo State in particular. Businesses were completely shut down, some doing skeletal services, some downsized, while some are still reducing the pay packet of their workers. However calamitous this scourge appears to be, it has some advantages to business. This is why Allinson, (2020) stated that every challenge brings immense joy and opportunities. Du-Plessi (2020) opined that the ravaging of the Black Death to Europe between 1347 and 1353 brought about reconstruction and renewal of European society. This set the pace for renaissance. Davies (2020) opined that technology industry is taking the advantage of COVID-19 to excel in cloud computing, electronic payments, and ecommerce, among others. This also in consonance with Ministry of Social Development New Zealand (2020) which provides wage subsidy and support to business during COVID-19, and save workers from being laid off. Olubiyi (2020) explained that the use of technology in the areas of distribution, sales, after-sales service, and inventory management will help rescue business dormancy during Covid-19. This will make market to be extended across borders with the introduction of e-commerce, shopping, bargaining, and transactions can be done anywhere which makes businesses accessible everywhere. E-commerce platform gives business owners the clear vision and the precautionary measures required during pandemic. During Covid-19 Pandemic, shopping cost, transaction and operational costs are drastically reduced. This can also enhance business to continue despite restriction orders. It is a 24-hour trading without physical contacts. Olubiyi concluded that during Covid-19 pandemic, business revenues and sales improved market reach, access to new markets and cost savings in marketing and communication expenditure are greatly enhanced. Russia Statistical Research Department (2020) stressed that coronavirus (COVID-19) outbreak has helped their company to produce desired result, as well as making their workers to be ready to work for less pay up to 20 percent. Russia Statistical Research Department further stated that Covid-19 has helped companies to take proactive decision in increasing its effectiveness, adoption of new technology, cutting costs, taking unpopular decisions, and having new opportunities. 
Imanche, Tasinda, Tian and Dalibi (2020) carried out a study on the effect of Covid-19 on SMEs in Nigeria and it revealed that the cessation of movement, reduction in consumer spending power and decrease in imported goods negatively affected SMEs in Nigeria. They also opined that due to Covid-19 pandemic only fewer investors were willing to pump money to enable the sustainability of SMEs while the decrease consumer spending automatically reduced the income of SMEs. The temporary closure of non-essential enterprises decreased output and production. A study carried out by Enemona, Muhammed and Usio (2020) on the effect of Covid-19 on SMEs in Lokoja, Nigeria revealed that Covid-19 inhibited normal SMEs activities and operations; reduced their income, increased prices of materials input and downsizing of workers, decline in demand for products due to restriction of movement. A study carried out by Oyewale, Adebayo and Kehinde (2020) on the effect of Covid-19 on Entrepreneurs in Nigeria revealed that majority of the entrepreneurs in Nigeria were affected by Covid-19 pandemic lockdown both severely and slowly which had increasing effect on low sales among enterprises especially for non-agricultural produce but contrary on agricultural produce (food).

\section{Methodology}

The descriptive survey research design was employed. One thousand one hundred and seventeen (1117) business owners in Edo State constituted the population. Random sampling technique was used to select a sample of two hundred and thirty five (235) respondents. Data was collected with the aid of a questionnaire made of two parts. Part ' $\mathrm{A}$ ' is respondents' bio-data; while ' $\mathrm{B}$ ' had 40 items measuring the various constructs identified in the research questions. The instrument was pilot tested by administering it on a sample of 30 respondents distinct from those of the study sample. The Cronbach Alpha form of reliability was carried out and a reliability coefficient value of 0.79 was obtained. The researcher engaged the services of six research assistants in administrating the questionnaires to business owners and data collected was analyzed using mean and standard deviation. The value of 2.50 was the mean criterion. Therefore, a calculated value greater than 2.50 was high extent while below 2.50 was low extent.

\section{Results}

Research Questions One: to what extent Covid-19 pandemic lockdown affected the sales volume of small and medium businesses in Edo State?

Table 1: Impact of COVID-19 on Sales Volume

\begin{tabular}{|c|c|c|c|c|}
\hline $\mathbf{S} / \mathbf{N}$ & Items on Sales Volume & $\bar{\chi}$ & S.D & Remark \\
\hline 1. & lantity of goods sold & 1.87 & 1.14 & LE \\
\hline 2. & h sales to customers & 1.84 & 1.02 & LE \\
\hline 3. & quick sales returns & 1.70 & 0.63 & $\mathrm{LE}$ \\
\hline 4. & total sales volume per day & 1.80 & 1.04 & LE \\
\hline 5. & availability of raw materials & 1.54 & 0.51 & LE \\
\hline 6. & regular stock re-ordering & 2.22 & 1.11 & LE \\
\hline 7. & quick distribution of finished goods & 1.99 & 1.01 & LE \\
\hline 8. & Focuse on improving sales velocity & 2.70 & 1.06 & $\mathrm{HE}$ \\
\hline \multicolumn{2}{|c|}{ Grand Mean } & 1.95 & 0.94 & LE \\
\hline
\end{tabular}

All the items were rated low extent except items No 8 that was rated high extent. The grand mean of 1.95 indicated low extent shows that sales volume was low during COVID-19 pandemic lockdown.

Research Questions Two: to what extent Covid-19 pandemic lockdown affected the cash flow of small and medium businesses in Edo State? Table 2: Impact of COVID-19 on Cash Flow

\begin{tabular}{|c|c|c|c|c|}
\hline $\mathbf{S} / \mathbf{N}$ & Items on Cash flow & $\bar{\chi}$ & S.D & Remark \\
\hline 9. & Paying of store rent & 2.70 & 0.63 & HE \\
\hline 10. & spending cash sales on households needs & 2.80 & 1.03 & $\mathrm{HE}$ \\
\hline 11. & spending on business Meetings & 2.07 & 0.95 & LE \\
\hline 12. & Payment of salaries & 2.62 & 0.54 & $\mathrm{HE}$ \\
\hline 13. & Savings for future business expansion & 1.38 & 1.88 & LE \\
\hline 14. & payment for overhead cost & 2.22 & 1.11 & LE \\
\hline 15. & withholding charges & 2.85 & 0.93 & $\mathrm{HE}$ \\
\hline 16. & Payment of interest on loans & 2.81 & 0.75 & $\mathrm{HE}$ \\
\hline 17. & bulk purchases & 1.99 & 1.01 & LE \\
\hline \multicolumn{2}{|c|}{ Grand Mean } & 2.38 & 0.98 & LE \\
\hline
\end{tabular}

Items $9,10,12,15$ and 16 were rated high extent while items $11,13,14$, and 17 were rated low extent with a grand mean of 2.38 which indicated that cash flow was low during COVID-19 pandemic lockdown. 
Research Questions Three: to what extent Covid-19 pandemic lockdown affected the profit margin of small and medium businesses in Edo State?

Table 3: Impact of COVID-19 on Profit of Business

\begin{tabular}{|c|c|c|c|c|}
\hline $\mathbf{S} / \mathbf{N}$ & Items on Profit Margin & $\bar{\chi}$ & S.D & Remark \\
\hline $1 \overline{8 .}$ & Customers' patronage & 1.30 & 0.62 & LE \\
\hline 19. & Pricing of goods and services & 1.80 & 1.03 & LE \\
\hline 20. & Selling expenses. & 2.46 & 0.50 & $\mathrm{LE}$ \\
\hline 21. & Cost of sustaining business & 3.01 & 1.00 & $\mathrm{HE}$ \\
\hline 22. & constant of supply & 1.16 & 1.08 & LE \\
\hline 23. & Delay in sales & 1.68 & 1.07 & LE \\
\hline 24. & Scarcity of goods & 3.09 & 0.91 & $\mathrm{HE}$ \\
\hline 25. & Time constraints & 3.02 & 0.43 & $\mathrm{HE}$ \\
\hline 26. & Charging high prices for goods & 3.09 & 1.07 & $\mathrm{HE}$ \\
\hline 27. & cost of anticipated risk protection & 2.89 & 1.51 & $\mathrm{HE}$ \\
\hline 28 & gross income per day & 2.09 & 0.92 & LE \\
\hline 29. & Cost of utility & 1.04 & 1.30 & $\mathrm{LE}$ \\
\hline 30. & Getting close to customers & 1.62 & 0.97 & LE \\
\hline 31 & high cost of reorder & 2.84 & 1.01 & $\mathrm{HE}$ \\
\hline Grand & Mean & 2.22 & 0.96 & $\mathbf{L E}$ \\
\hline
\end{tabular}

Items 21,24, 25, 26, 27 and 31 were rated high extent while items 18,19, 20,22, 23, 28, 29 and 30 were rated low extent. The grand mean of 2.22 indicated that all the profit margin was low.

Research Question Four: What are the possible strategies for effective small and medium businesses management amidst COVID-19 era?

Table 4: Possible Strategies for Effective Small and Medium Business management amidst COVID-19 Era

\begin{tabular}{|c|c|c|c|c|}
\hline $\mathbf{S} / \mathbf{N}$ & Items on Advantages & $\bar{\chi}$ & S.D & Remark \\
\hline 32. & online business meetings & 2.89 & 0.90 & $\mathrm{HE}$ \\
\hline 33. & online business conferencing & 2.85 & 1.13 & $\mathrm{HE}$ \\
\hline 34. & Electronic payments & 3.46 & 0.51 & $\mathrm{HE}$ \\
\hline 35. & E-commerce platforms & 3.00 & 0.71 & $\mathrm{HE}$ \\
\hline 36. & Accessibility to E-business summit & 3.11 & 0.53 & $\mathrm{HE}$ \\
\hline 37. & Online purchase order & 3.12 & 1.07 & $\mathrm{HE}$ \\
\hline 38. & online sales & 3.03 & 0.73 & $\mathrm{HE}$ \\
\hline 39. ad & ncement in ICT utilization to entrepreneurs & 2.84 & 0.99 & $\mathrm{HE}$ \\
\hline 40. & vernment provision of internet security & 2.74 & $0.84 \mathrm{HE}$ & \\
\hline \multicolumn{2}{|c|}{ Grand Mean } & 3.00 & 0.82 & HE \\
\hline
\end{tabular}

\section{Source: Researcher's fieid study (2020)}

All the Items rated high extent with a grand mean of 3.00 which indicated that all the items raised promote effective small and medium business management amidst Covid-19 era

Discussion of Findings

The findings of the study revealed that sales volume was very low during COVID-19 pandemic lockdown. The finding is also in agreement with Bodnar (2019) who opined that sales volume dropped considerably during COVID-19 lockdown period. The finding is in agreement with White (2020) who stated that the Coca-Cola company sale volume dropped during COVID-19 lockdown and reported that Coca-Cola company global sales volumes fell by $25 \%$ in the first quarter of 2020 . This finding is in consonance with Aman (2020) who stated that the auto sector has been badly affected by Covid-19 lockdown resulting from the sales of vehicle dropping to 683,000 units. Aman further stated that the sales of vehicles dropped to 197,000 units compared to 328,000 units in 2019. Also it is agreement with Imanche, Tasinda, Tian and Dalibi (2020) who stated that due to Covid-19 pandemic lockdown only fewer investors were willing to pump money to enable the sustainability of SMEs resulting in the decrease of consumer spending and automatically reduced the income of SMEs. It also agreed with Oyewale, Adebayo and Kehinde (2020) who stated that Covid-19 pandemic lockdown affect entrepreneurs both severely and slowly which had increasing effect on low sales among enterprises especially for non-agricultural produce (foodstuff).

The findings equally revealed that cash flow was very low during COVID-19. This is in consonance with Tulder (2020) who opined that businesses cash flow is significantly impeded and discount rates higher during COVID-19 lockdown era. The researcher also opined that COVID-19 lockdown brought liquidity issues to businesses thereby making companies to be distressed financially. The finding is also in consonance with Finkel (2020), who emphasized that during COVID-19 lockdown business expenses appear too high in relation to volume of sales which invariably affects cash flow. The finding is in consonance with ACCA Canada (2020) which reported that Covid-19 has negatively 
affected employee productivity by $52 \%$, launch of new products or services by $27 \%$ and cash flow stood at $23 \%$. The finding is also in agreement with Foss (2020) who stated that as a result of the coronavirus lockdown, business owners are experiencing tight cash flow to run various arms of their businesses. The finding is also in agreement with Foss, Shah (2020) who maintained that the major problem confronting business in this Covid-19 pandemic era is the issue of cash flow which has been a hindrance to many organizations.

The findings also revealed that profit margin was low during COVID-19 pandemic lockdown. The finding is in agreement with the findings of LaPointe (2020) who maintained that there was a drop in profit generated by hospital compared to previous periods before Covid-19. This may not be unconnected with the fact that people were scared to go to the hospital to treat other ailments for fear of contacting Covid-19. It also agreed with Goldstein (2020) who stated that big companies used their reserves to give out loans to companies on high interest rate. It also agreed with Kim (2020) who reported that the Consumer Electronics Division recorded lower earnings as a result of COVID-19 lockdown compared to a year before. The finding of Kilpatrick, Dess, and Barter (2020) also agreed with the findings which stated that tourism, hospitality, entertainment and air transportation felt the negative impact of Covid-19 with complete shut down. Singh (2020) finding is also in consonance with the findings which reported that Puma's sales declined in the first quarter of 2020 due to impact of Coronavirus pandemic that is ravaging the global market. It also agreed with Enemona, Muhammed and Usio (2020) who stated that the effect of Covid-19 in nigeria inhibited normal SMEs activities and operations and reduced their income. The findings also contradicted Ludwig (2020) assertion who maintained that food delivery services were in high demand also with Egba (2020) who stated that MTN Telecommunication Company made a steady growth during the pandemic period owing to the enforced lockdown. This may not be far from the fact that people were indoors and the only means of reaching out was through mobile communication and online services. The finding also contradicted Switzerland (2020) who reported that e-commerce sales reached $29.4 \%$ which exceeded $10 \%$ of total Group sales before Covid-19. The finding is equally in contrast with Coonrod (2020) who stressed that distiller of Missouri Ridge Distillery maximized an increase of profit in the production of hand sanitizer during Covid-19 pandemic. Basically it would be recalled that hand sanitizer was among the essential products that were in high demand because of its peculiarity to control the widespread of the pandemic.

Moreso the finding is in agreement with Davies (2020) who noted that technology industry took the advantage of COVID-19 to excel in computing, electronic payments and ecommerce. The finding is in agreement with Allinson (2020) who stated that every challenge brings immense joy and opportunities. The finding agrees with Du-Plessi (2020) who stated that the ravaging of the Black Death to Europe between 1347 and 1353 brought about reconstruction and renewal of European society to set the pace for renaissance. The finding is in consonance with Dorsey (2020) who noted that during pandemic, governments set aside their differences to have a political will and foresight to build a world good for all that will be equitable politically, economically and socially. The finding is in consonance with Olubiyi (2020) who explained that the use of technology in the areas of distribution, sales, after-sales service, and inventory management will help rescue business dormancy during Covid-19 era. This will allow markets to be extended across borders with the introduction of E-commerce, shopping, bargaining, and transactions anywhere which makes businesses accessible everywhere daily irrespective of location. E-commerce platform will give business owners the clear vision and the precautionary measures required during pandemic. During Covid-19 pandemic, shopping cost, transaction and operational costs, are drastically reduced. This can also enhance business to continue despite restriction orders and it's a 24-hour trading without physical contacts. Olubiyi concluded that during pandemic, business revenues and sales, improve market reach, access to new markets and cost savings in marketing and communication expenditure will greatly be enhanced. The findings agrees with Russia Statistical Research Department (2020) which stressed that coronavirus (COVID-19) outbreak has helped their company to produce desired result, as well as making their workers to be ready to work for less pay up to 20 percent. Russia Statistical Research Department further stated that Covid-19 has helped companies to take proactive decision in increasing its effectiveness, adoption of new technology, cutting costs, taking unpopular decisions, and having new opportunities.

\section{Conclusion}

Since COVID-19 enforced a new lifestyle of normal on all people; irrespective of race, nationality and status it became expedient to explore approach to ensure that small and medium businesses continuous to thrive because of the peculiarity to economic growth and development. The study therefore investigated the impact on SMEs which revealed that it negatively affected businesses sales volume, cash flow and profit margin. However essential goods such as foodstuffs and drugs had positive boost during the period of the cessation, restriction of movement and temporary lockdown because of their peculiarity to human survival and sustainability. Therefore, business owners should engage more in online sales to increase sales volume, cash flow, profit margin and also develop strategies for massive savings to enable them surmount crises that could be contingent and inimical to businesses.

\section{Recommendations}

1. Business owners should stay in close contact with their customers through online sales and e-business operations.

2. Business owners should closely work with their vendors and suppliers to avoid cash crunch and ensure steady cash flow.

3. Business owners should be more ICT compliance to enable their effective utilization for business operations.

4. Business owners could use e-platforms for their business meetings, conferences, conventions and summits.

5. Government should ensure adequate cyber security to enable effective e-business operation devoid of internet fraud on business owners. 
6. Business owners should develop strategies for massive savings to enable them surmount crises that could be contingent and inimical to their businesses

\section{Contribution to Knowledge}

The study has empirically provided insights for effective business management amidst Covid-19 and advocated adequate steps to be taken to salvage the situation. The findings of the study will help business owners whose businesses are already collapsing amidst Covid19 to revamp the sales volume, increase cash flow and maximize profit.

\section{References}

ACCA Canada (2020). Covid-19: Employee productivity, cash flow, new products and services

all impacted by the effects of the pandemic, finds new research. Retrieved

from https://www.globenewswire.com/news-mnrelease/2020/04/16/2017262/0/en/Covid-19-Employee-productivity-cash-flow-new-products-andservices-all-impacted-by-the-effects-of-the-pandemic-finds-new-research.html

Accounting Tools (2020). Sales volume. Retrieved from https://www.accountingtools.com

Akanni, L.O. (2020). The implication of Covid-19 pandemic on the Nigerian economy. Retrieved from http://cseaafrica.org/the-implication-of-covid19-on-the-nigerian-economy/

Allison, A.K. (2020). Fighting COVID-19 is my contribution to my country. Retrieved from https://www.un.org/africarenewal/web-features/coronavirus/healthcare/fighting-covid-19-my-contribution-my-country

Aman, M. (2020). Weekly update: COVID-19 impact on global automotive industry. Retrieved from https://www.counterpointresearch.com/weekly-updates-covid-19-impact-global-automotive-industry/

Bianco, C. (2020). Infected: The impact of the coronavirus on the Middle East and North Africa.

European Council on Foreign Relations. Retrieved from

https://www.ecfr.eu/commentary-infected-the-impact-of-the-corona-virus-on-the-middle-

Bodnar, K. (2019). Deal volume and sales response rates drop to new lows COVID-19 benchmark data, updated weekly]. Retrieved from https://blog.hubspot.com/marketing/covid-19-benchmark-data-edition2

Chilufa, C. (2020). The African economy is "infected": The economic impact of COVID-19 is worsening poverty in Africa. Retrieved from https://xavier.network/news/the-african-economy-is-infected-the-economic-impact-of-covid-19-is-worsening-poverty-in-africa/

Coonrod, M. (2020). COVID-19 Coverage: Slim profit margin still helps. Retrieved from https://sbj.net/stories/covid-19-coverage-slim-profit-margin-still-helps, 68949

Corporate Finance Institute (2020). Cash flow. Retrieved from https://corporatefinanceinstitute.com/resources/knowledge/finance/cash-flow/

Davies, B. (2020). What is a Business? - Definition, characteristics \& examples. Retrieved on from https://study.com/academy/lesson/what-is-a-business-definition-characteristics-examples.html

Dorsey, J.M. (2020). Refugees and Shantytowns in MENA and beyond imperil global public health commentary No. 598. Middle East Institute. Retrieved from https://www.mei.org.in/commentary-598.

Duke II, J (2010). Small and medium enterprise equity investment scheme as funding strategy for SMEs in nigeria. Retrieved from http://researchgate.netpublication/256051975-small-medium-enterprise-equity-investment-scheme-as-funding-strategy-for-smes-in-nigeri

Du Plessis, Q. (2020). An unprecedented crisis: The economic ramifications of Covid-19. Mail and Guardian. Retrieved from https://www.mg.co.za/article/2020-04-04-an-unprecedented-crisis-the-economic-ramifications-of-covid-19

Egba, L. (2020). Analysis: MTN's blow out Q1 profit vs Covid-19 headwinds. Retrieved from https://nairametrics.com/2020/05/12/analysis-mtns-blow-out-q1-profit-vs-covid-19-headwinds/

Enemona, N.A. Muhammed, A.A. \& Usio, U.T. (2020). Covide-19 pandemic and performance of small and medium scale enterprises in Lokoja, Kogi State, Nigeria. Ilorin Journal of economic policy. Department of economic university of Ilorin. 7 (3) 41-50. Retrieved from http://ideas.respct.org/a/ris/ilojep/0033.html

European Centre for Diseases Prevention and Control (2020). Coronavirus disease. Retrieved from https://www.ecdc.europa.eu/en

Finkel, D. (2020). The 4 most common causes of cash flow challenges (and what to do about them). Retrieved from https://www.inc.com/david-finkel/the-4-most-common-causes-of-cash-flow-challenges-and-what-to-do-about-them.html

Foss, K. (2020). How will COVID-19 impact your cash flow? Retrieved on $2^{\text {nd }}$ June 2020 from https://www.bradymartz.com/news/how-will-covid-19-impact-your-cash-flow/

Goldstein, M. (2020). Some big investors smell profit in virus-plagued companies. Retrieved from https://www.nytimes.com/2020/04/03/business/private-equity-hedge-funds-coronavirus.html

Harding, A. (2020). The 12 dealiest viruses on earth. Retrieved from https://www.livescience.com/56598

Hayes, A. (2019). What is business? Retrieved from https://www.investopedia.com/terms/b/business.asp

Ibekwe, N. (2020). COVID-19: Arik cuts salaries by $80 \%$, places $90 \%$ of staff on leave without pay. Retrieved from https://www.premiumtimesng.com/business/business-news/389578 Influencer Marketing Hub (2020). Covid-19 marketing reports: Statistics and Ad spend. Retrieved from https://influencermarketinghub.com/coronavirus-marketing-ad-spend-report/

Imanche, Tasinda, Tian and Dalibi (2020). Effct of Covid-19 pandemic on small and medium scale businesses in nigeria. International journal of research publication 56 (1) 34-45. Retrireved from http://.www.researchgate.net/publication/343227851-effect-of-covid-19-pandemic-on-small-and-mediumscale-business-in-nigeria

Johnson, R. (2019). What are the benefits of making profits? Retrieved from 
https://smallbusiness.chron.com/benefits-making-profit

Kilpatrick, J., Dess, J. \& Barter, L. (2020). Managing cash flow during a period of crisis.

Retrievedfrom https://www2.deloitte.com/content/dam/Deloitte/global/Documents/About-Deloitte/gx-COVID-19-managing

Kim, K.N. (2020). Samsung Electronics announces first quarter 2020 results. Retrieved from https://news.samsung.com/global/samsung-electronics-announces-first-quarter-2020-results

Kokemuller, N. (2020). Advantages and disadvantages of sales volume-based quota system. Retrieved from https://smallbusiness.chron.com/advantages-disadvantages-sales-volume-based-quota-system

LaPointe, J. (2020). Hospital revenues rose, margins fell before COVID-19 outbreak. Retrieved from https://revcycleintelligence.com/news/hospital-revenues-rose-margins-fell-before-covid-19-outbreak

Ludwig, S. (2020). 15 small businesses thriving during coronavirus. Retrieved from https://www.uschamber.com/co/start/strategy/coronavirus-successfulbusinesses

Meyer, S. (2020). Understanding the COVID-19 effect on online shopping behavior. Retrieved from https://www.bigcommerce.com/blog/covid-19-ecommerce/\#understanding-panic-buying-and-coronavirus

Ministry of Social Development New Zealand (2020) COVID-19 support for employers. Retrieved from https://workandincome.govt.nz/covid-19/support-for-employers.html

$\mathrm{Ng}$, A. (2020). Three ways the corona virus could have an impact on Middle East economies. Retrieved from https://www.cnbc.com/2020/03/12/three-ways-the-corona-virus-could-impact-the-middle-east-economies.html.

Olubiyi, T. (2020). COVID-19: Hidden advantage for SMEs. Retrieved from https://businessday.ng/opinion/article/covid-19-hidden-advantage-for-smes/

Onyekwena, C. \& Ekeruche, M.A. (2020). Understanding the impact of the COVID-19 outbreak on the Nigerian economy. Retrieved from https://www.brookings.edu/blog/africa-in-focus/2020/04/08/understanding-the-impact-of-he-covid-19

Oriazowanlan, A. O., Olowo-Onyanemi Z.O. \& Umunna L.A. (2008). Investigation into why small and medium enterprises (SMEs) fail in nigeria. Technical and Vocational Education Journal of the Department of Vocational and technical education, university of benin, benin-city. 1(2) 103-110.

Ozili, P.K. \& Arun, T.G. (2020). Spillover of COVID-19: impact on the global economy. Working paper. Retrieved from file:///C:/Users/USER/AppData/Local/Temp/covid19nigeriacoronavirus.pdf

Riboua, Z. (2020). Coronavirus experiences on the ground in the Middle East. Atlantic Council. Retrieved from https://www.atlanticcouncil.org/blogs/menasources/coronavirus-experiences-on-theground-in-the-middle-east

Russia Statista Research Department (2020). Are there positive changes for business in general over the period of the coronavirus epidemic? Retrieved from https://www.statista.com/statistics/1108918/russia-covid-19-advantages-for-business/

Seen, C.M. (2020). Impact of COVID-19 on transfer pricing arrangements. Retrieved from https://home.kpmg/my/en/home/insights/2020/03/the-business-implications-of-coronavirus/impact

Shah, H. (2020). How CFOs can minimize the impact of Covid-19 and build business resilience in times of disruption. Retrieved from https://economictimes.indiatimes.com/small-biz/money/how-cfos-can-minimise-the-impact-of-covid-19-and-build-business-resilience-in-timesofdisruption/articleshow/75217039.cms

Shaulova, E. (2020). Impact of COVID-19 on OTC healthcare sales in Italy 2020. Retrieved from https://www.statista.com/statistics/1110867/impact-of-covid-19-on-otc-healthcare-sales-in-italy/

Shereen, M.A., Khan, S., Kazmi, A., Bashir, N., \& Siddique, R. (2020). COVID-19 infection: Origin, transmission, and characteristics of human coronaviruses. Journal of Advanced Research, 24, 91-98

Singh, M. (2020). Xiaomi reports Q4 revenue jump, beats estimates. Retrieved from https://techcrunch.com/2020/03/31/xiaomi-q4-annual-2019/

Switzerland, V. (2020). Nestlé reports three-month sales for 2020, provides COVID-19 update. Retrieved from https://www.nestle.com/media/pressreleases/allpressreleases/three-month-sales-2020

Tregurtha, K. (2020). 5 ways to solve small business cash flow problems during COVID-19. Retrieved from https://www.ondeck.com/resources/5-ways-to-maximize-cash-flow-during-the-covid-19-outbreak

Tulder, K.N. (2020). Covid-19: Valuation challenges and opportunities. Retrieved from http://www.taeconomics.com/covid-19-valuation-challenges-and-opportunities

White, M. (2020). Coca-Cola sales volume declines $25 \%$ in April due to Covid-19 impact. Retrieved from https://www.foodbev.com/news/coca-cola-sales-volume-declines-25-in-april-due-to-covid-19

Wikipedia, free encyclopedia (2020). Business. Retrieved from http://en.wikipedia.org/wiki/business

York, M. (2019). 6 ways to increase profits for your small business. Retrieved from https://www.the-balancesmb.com/steps-to-increase-small-business-profits 